\title{
Seasonal and spatial variation of solar radiation in Nepal Himalayas
}

\author{
Sunil Adhikary \\ Department of Meteorology \\ Tri-Chandra Multiple Campus, Tribhuvan University, Kathmandu, Nepal.
}

\begin{abstract}
Solar radiation data (two-hourly data from 1987 to 1999) observed at high altitude meteorological stations in Nepal Himalayas were analyzed to study seasonal and spatial variation of solar radiation and shed some light on solar energy potential and prospect of vegetation development in the mountainous region of Nepal. Results showed significant similarities and differences on solar radiation with respect to seasons and locations (altitudes). Mean seasonal amount of solar radiation was generally higher in spring than in summer. The significant amount of monsoonal clouds in the summer hindered incoming solar radiation during summer, while less or no clouds during spring allowed more solar radiation to reach the earth's surface. Absolute extreme values of solar radiation in the mountainous regions during fine weather conditions were close to the solar constant (1367 $\left.\mathrm{Wm}^{-2}\right)$ due to negligible depletion of radiation within the atmosphere. Amount of solar radiation increased with altitude due to smaller optical depth of the atmosphere at higher altitudes. The increasing rate of annual mean solar radiation with altitude is found to be $90 \mathrm{Wm}^{-2} \mathrm{~km}^{-1}$ in the mountainous region of Nepal.
\end{abstract}

Keywords: Solar radiation, high-altitude, atmosphere, solar constant, Nepal Himalayas.

\section{INTRODUCTION}

Nepal is a landlocked mountainous country with a fragile and steep topography about 60 meter above mean sea level ( $m$ a.s.1.) in the south to $8,848 \mathrm{~m}$ a.s.1. in the north. It is located on the southern slopes of the Himalayas between $26^{\circ} 22^{\prime} \mathrm{N}$ to $30^{\circ} 27^{\prime} \mathrm{N}$ and $80^{\circ} 4^{\prime} \mathrm{E}$ to $88^{\circ} 12^{\prime}$ E. Total land surface area of Nepal is $147,181 \mathrm{~km}^{2}$; approximately $885 \mathrm{~km}$ east-west and $145 \mathrm{~km}$ at its narrowest to $241 \mathrm{~km}$ at its broadest, north-south (Figure1). Nepal is a country of diverse climates and topography from sub-tropical to alpine as a result of high gradient in its North-South direction (Nayava, 2012). Physiographically, the country can be

Email: sunirus2003@yahoo.com

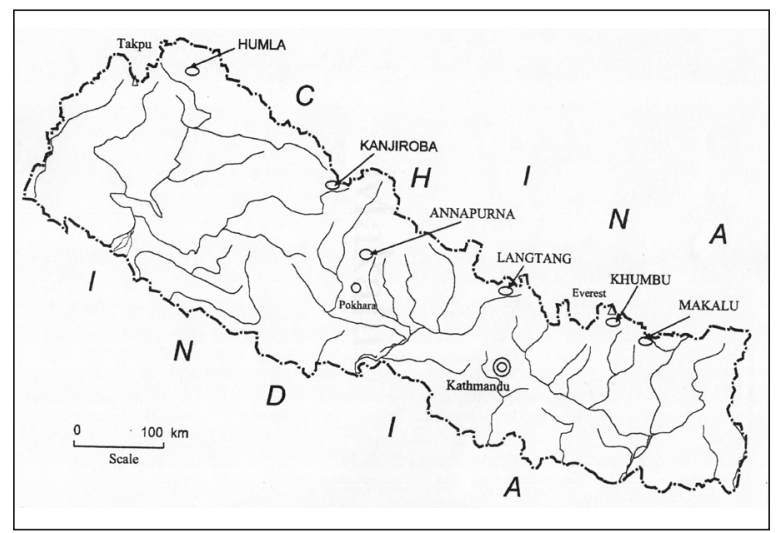

Figure 1: Map of Nepal showing high altitude meteorological stations in Nepal Himalayas.

divided into different land units from south to north. These are Terai (plain land area), Siwalik range, Mahabharat range, the Great Himalaya 
and Trans-Himalayas. These land units receive different amounts of solar radiation in different seasons from the sun. The utilization of solar energy (both thermal and electrical) for daily uses depends on available solar insolation. In particular, solar energy has been proved to be a very important alternative source of energy to fulfill the most basic electricity needs (through photovoltaic technology) to the people in Nepal Himalayas (Schweizer et al., 1995, SchweizerRies and Preiser, 1997). Knowledge on seasonal (or monthly) and spatial distribution of solar energy is important for proper energy planning and to achieve optimum efficiency from the overall thermal/electrical system (Umeno, 2003). In addition to the energy uses, phenological responses in terms of vegetation development also depend upon available solar radiation. The utmost importance of solar radiation for energy uses and vegetation development can be summarized below.

1. Solar radiation is clean and renewable energy, and very useful especially for a mountainous country like Nepal.

2. Sunlight is the source of energy that green plants use in the process of photosynthesis to transform into chemical energy (either/ or cut).

3. Solar radiation plays a major role as a source of energy in the process of evaporation/ evapotranspiration that determines the vegetation water requirement.

Climate of any region is controlled by solar radiation input. The sun provides approximately $99.97 \%$ of the energy required for the physical processes taking place in the earth-atmosphere system (Ibrahim, 1985; Oke, 1999). Spatial and temporal (monthly/seasonal) variations of solar radiation play a decisive role in determining the long-term and short-term variations of the climatic elements. The purpose of this paper is to report seasonal/monthly and spatial variation of solar radiation and to shed some light on solar energy potential and prospect of vegetation development in the mountainous region of Nepal.

\section{DATA AND METHOD}

Solar radiation (Global radiation) data from

Table 1: High-altitude meteorological stations in Nepal Himalayas.

\begin{tabular}{|l|c|c|c|}
\hline Name of station & Latitude (N) & Longitude (E) & Altitude (m a.s.l.) \\
\hline Kanjiroba (Hurikot) & $29^{\circ} 07^{\prime}$ & $82^{\circ} 36^{\prime}$ & 2735 \\
\hline Annapurna (Machapuchhare Base Camp) & $28^{\circ} 32^{\prime}$ & $83^{\circ} 57^{\prime}$ & 3470 \\
\hline Langtang (Kyangjing) & $28^{\circ} 13^{\prime}$ & $85^{\circ} 37^{\prime}$ & 3920 \\
\hline Khumbu (Dingboche) & $27^{\circ} 53^{\prime}$ & $86^{\circ} 50^{\prime}$ & 4355 \\
\hline Makalu (Sipton-La) & $27^{\circ} 40^{\prime}$ & $87^{\circ} 13^{\prime}$ & 3980 \\
\hline
\end{tabular}

high altitude meteorological stations (Figure. 1 and Table 1) in Nepal Himalayas were analyzed in this study. The Global radiation (i.e. a combination of direct solar radiation and diffuse sky radiation) striking the surface of the earth was recorded by actinograph (Thies CLIMA) that utilizes the thermal effect of the radiation and records this as an amount of energy. The sensor system on the case of the actinograph consists of one black and two white coplanar bimetallic surfaces. The surfaces have been mounted in such a way that the thermal radiation which is reflected by the white surfaces but absorbed by the black one deflects this black surface and this deflection, in turn, causes a pointer to move for data recording on the recording strip chart. The 
spectral range and degree of transmission of the instrument are from $300 \mathrm{~nm}$ to $3000 \mathrm{~nm}$, and $3500 \mathrm{~nm}>90 \%$ respectively. The measuring range and operating temperature range are 0 to $1300 \mathrm{Wm}^{-2}$ and $-40{ }^{\circ} \mathrm{C}$ to $80^{\circ} \mathrm{C}$ respectively. In order to maintain data quality maintenance and calibrations of the instrument were performed regularly (i.e. every six or twelve months' interval) in the field.

The monthly mean solar radiation for each station was calculated based on 12-hour mean value (daily mean: 06:00 - 18:00) evaluated from semi-automatically recorded two-hour mean values (DHM, 1992-1999). Similarly, seasonal mean solar radiation was derived from monthly mean values that fall under each respective season. The data availability in this study (Kanjiroba: 1993-1995 and 1999; Annapurna, Langtang and Khumbu: 19871994; and Makalu: 1993 and 1994) varies from station to station, because of the discontinuity and loss of data owing to remoteness causing delay in maintenance, repair and replacement of malfunctioning instruments. Also, absolute extreme solar radiation data from all the meteorological stations observed in specific day of each month of 1993 were utilized in this study.

\section{RESULTS}

Figure 2 shows variation of monthly maximum, mean and minimum solar radiation in Kanjiroba (Hurikot) region. The bold solid lines represent

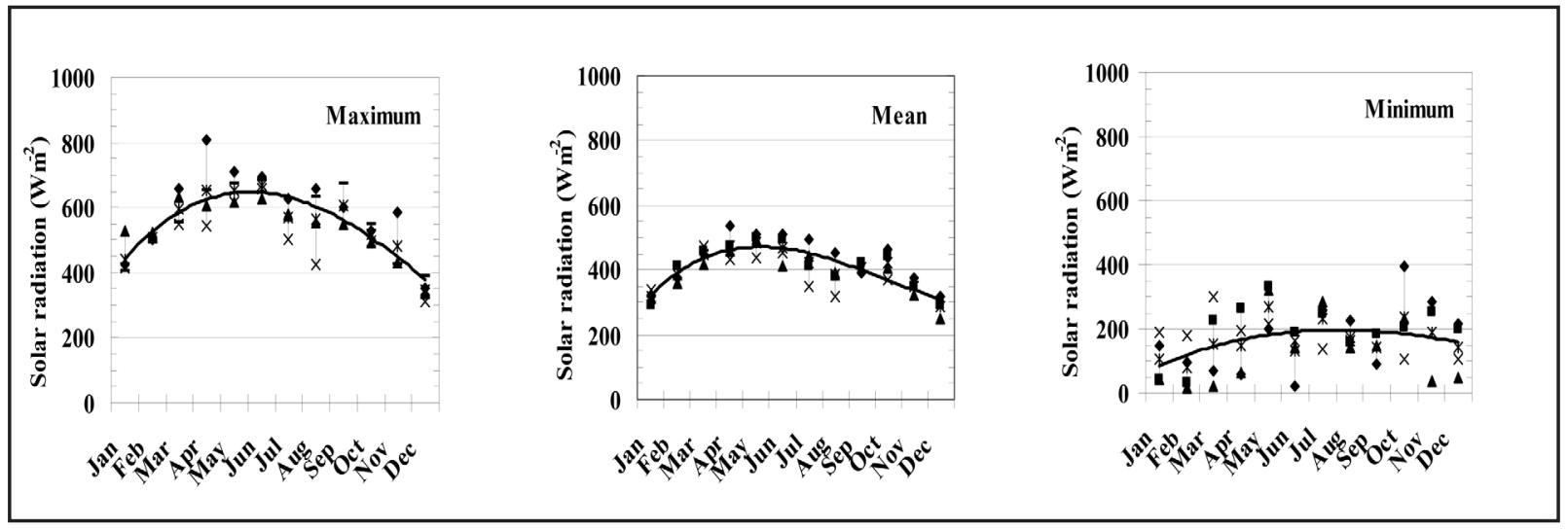

Figure 2: Monthly Maximum, mean and minimum solar radiation recorded at Kanjiroba (Hurikot) meteorological station.

the best fit to the corresponding data set. Monthly maximum solar radiation is about 600-700 $\mathrm{Wm}^{-2}$ for March-August, while rest of the months (January-February and SeptemberDecember) it is about $400-600 \mathrm{Wm}^{-2}$. Mean monthly solar radiation is about $400-500 \mathrm{Wm}^{-2}$ for March-August, while rest of the months (January-February and September-December) receive approximately $350 \mathrm{Wm}^{-2}$. Monthly minimum solar radiation increases steadily from January $\left(100 \mathrm{Wm}^{-2}\right)$ to October reaching the peak value of about $200 \mathrm{Wm}^{-2}$.

Figure 3 shows monthly maximum, mean and minimum solar radiation in Annapurna Machapuchhare base camp area. The bold solid lines represent the best fit to the corresponding data set. Monthly maximum solar radiation trend shows nearly a parabolic shape reaching the peak value of about $650 \mathrm{Wm}^{-2}$ in June. In terms of absolute values, the parabolic curve can be divided into three periods; $650 \mathrm{Wm}^{-2}$ for May-July, 400-600 $\mathrm{Wm}^{-2}$ for February-April and August-October, and $300 \mathrm{Wm}^{-2}$ for January and November-December. Mean monthly solar radiation is about $450 \mathrm{Wm}^{-2}$ for April-June, while rest of the months (January-March and July- 


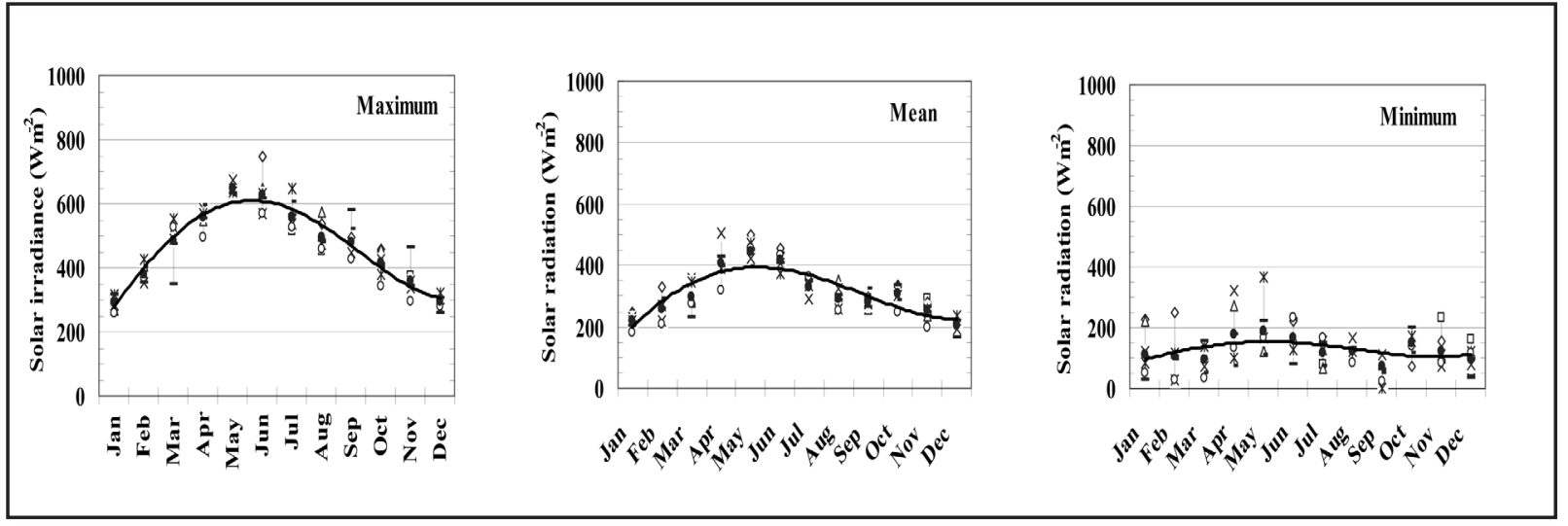

Figure 3: Monthly Maximum, mean and minimum solar radiation recorded at Annapurna (Machapuchhare B.C.) meteorological station.

December) receive approximately $300 \mathrm{Wm}^{-2}$. Monthly minimum solar radiation confines within $200 \mathrm{Wm}^{-2}$ throughout the whole year.

Figure 4 shows monthly maximum, mean and minimum solar radiation in Langtang, Kyangjing region. The bold solid lines represent the best fit to the corresponding data set. Monthly maximum solar radiation trend shows nearly a parabolic shape. Monthly maximum solar radiation is in the range of $600-1000 \mathrm{Wm}^{-2}$ for March-September, while for rest of the months (January-February and October-December) the range is $400-600 \mathrm{Wm}^{-2}$. Mean monthly solar radiation generally confines within the range of 400-600 $\mathrm{Wm}^{-2}$ except for January and December. Monthly minimum solar radiation fluctuates throughout the year from the average value of $200 \mathrm{Wm}^{-2}$.

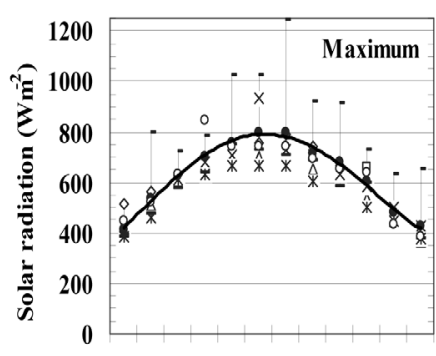

c日e

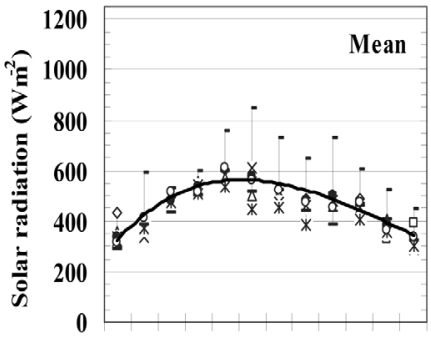

20

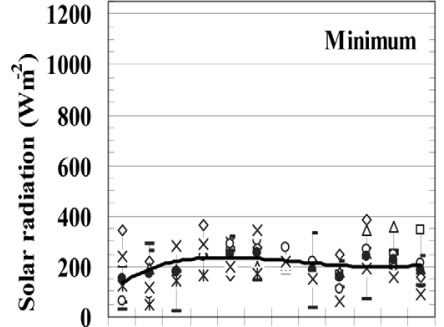

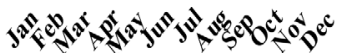

Figure 4: Monthly Maximum, mean and minimum solar radiation recorded at Langtang (Kyangjing) meteorological station.

Figure 5 shows monthly maximum, mean and minimum solar radiation in Khumbu, Dinboche region. The bold solid lines represent the best fit to the corresponding data set. Monthly maximum solar radiation is in the range of 600 $800 \mathrm{Wm}^{-2}$ for March-September, while for rest of the months (January-February and OctoberDecember) the range is $400-600 \mathrm{Wm}^{-2}$. Mean monthly solar radiation is about $500 \mathrm{Wm}^{-2}$ for March-October, and for rest of the months it is about $300 \mathrm{Wm}^{-2}$. Monthly minimum solar radiation is less than $200 \mathrm{Wm}^{-2}$ for January and 


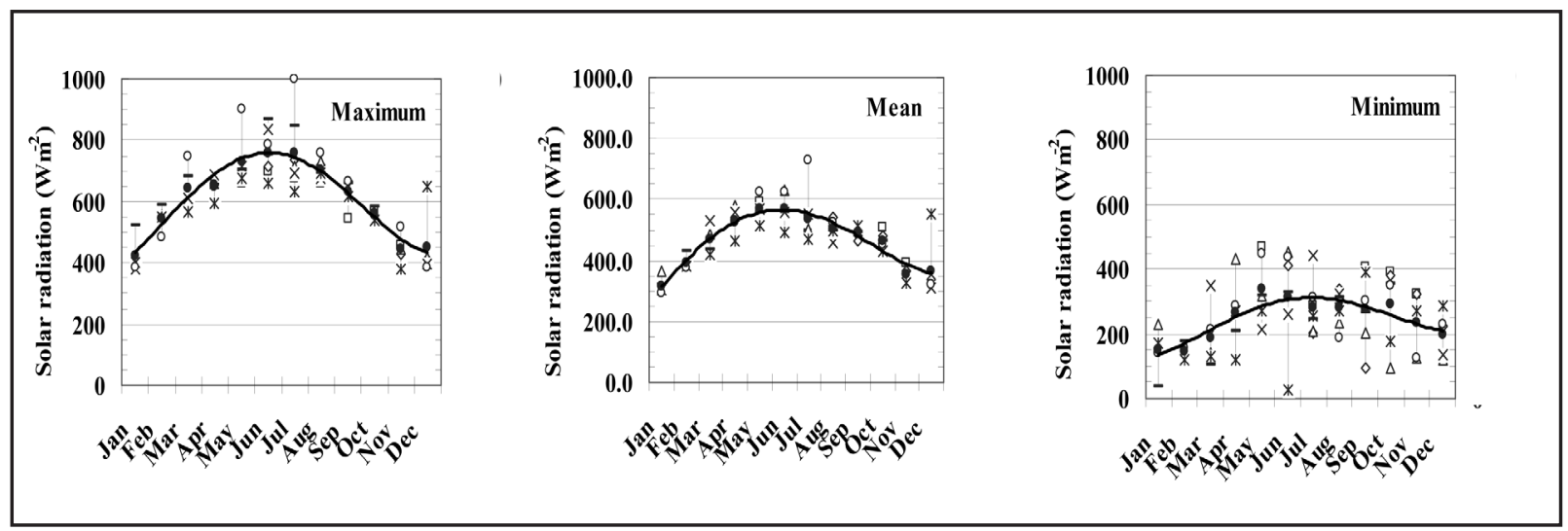

Figure 5: Monthly Maximum, mean and minimum solar radiation recorded at Khumbu (Dingboche) meteorological station.

February, while for rest of the months (MarchDecember) it is in the range of $200-400 \mathrm{Wm}^{-2}$.

Figure 6 shows monthly maximum, mean and minimum solar radiation in Makalu, Sipton-La area. The average monthly maximum, mean and minimum solar radiation are $500 \mathrm{Wm}^{-2}, 300$ $\mathrm{Wm}^{-2}$ and $100 \mathrm{Wm}^{-2}$ respectively.

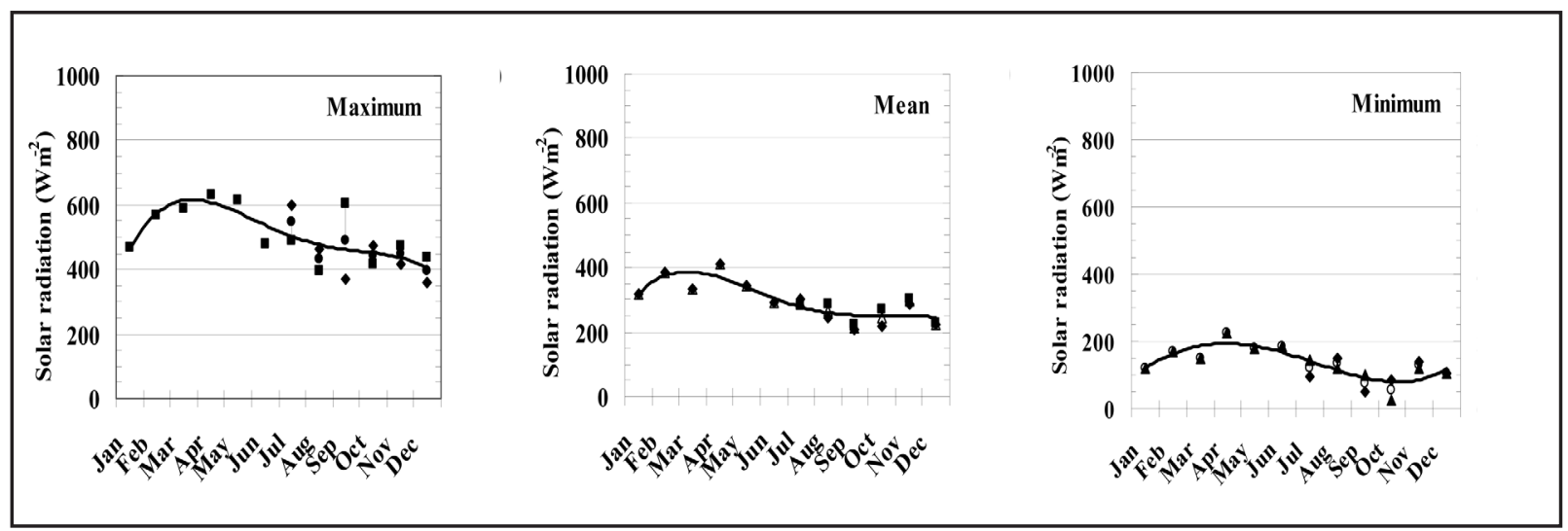

Figure 6: Monthly maximum, mean and minimum solar radiation recorded at Makalu (Sipton-La) meteorological station.

Table 2 shows the comparative statistics of the monthly maximum, mean and minimum solar radiation in Kanjiroba, Annapurna, Langtang, Khumbu and Makalu. In Kanjiroba, Annapurna and Langtang mean solar radiation reached minimum in December near the winter solstice, while the maximum was not seen in June near the summer solstice, but in May before the rainy season. In Khumbu mean solar radiation reached a minimum in January, and maximum in May $\left(570.5 \mathrm{Wm}^{-2}\right)$ and June $\left(570.8 \mathrm{Wm}^{-2}\right)$. In Makalu mean solar radiation appeared maximum in April, while minimum was seen in September. The annual mean solar radiation of Langtang (471.4 $\mathrm{Wm}^{-2}$ ) and Khumbu (464.2 $\mathrm{Wm}^{-2}$ ) are very similar, while of Kanjiroba (404.3 $\left.\mathrm{Wm}^{-2}\right)$, Annapurna $\left(310.0 \mathrm{Wm}^{-2}\right)$ and Makalu (302.6 $\mathrm{Wm}^{-2}$ ) are about 15\%, 35\% and $35 \%$ smaller than those of Langtang and Khumbu respectively.

Figure 7 shows mean seasonal variation of solar radiation. It is clear in the figure that absolute values and characteristics of seasonal variation 
Table 2: Monthly maximum, mean and minimum solar radiation $\left(\mathrm{Wm}^{-2}\right)$ observed at the meteorological stations in Nepal Himalayas.

\begin{tabular}{|l|l|l|l|l|l|l|l|l|l|l|l|l|l|l|l|l|l|}
\hline & \multicolumn{1}{l}{ KANJIROBA } & \multicolumn{3}{l}{ ANNAPURNA } & \multicolumn{3}{l|}{ LANGTANG } & \multicolumn{3}{l|}{ KHUMBU } \\
\hline & Max. & Mean & Min. & Max. & Mean & Min. & Max. & Mean & Min. & Max. & Mean & Min. & Max. & Mean & Min. \\
\hline January & 442.5 & 316.9 & 103.8 & 291.4 & 221.1 & 109.9 & 414.9 & 336.0 & 153.0 & 420.5 & 316.9 & 150.2 & 470.0 & 320.0 & 122.0 \\
February & 507.8 & 383.3 & 81.0 & 379.4 & 259.3 & 106.4 & 538.3 & 411.3 & 171.9 & 545.4 & 392.7 & 147.4 & 566.0 & 388.0 & 172.0 \\
March & 596.3 & 448.7 & 154.0 & 485.3 & 294.8 & 94.3 & 625.0 & 482.0 & 180.5 & 641.2 & 468.6 & 186.8 & 588.0 & 332.0 & 152.0 \\
April & 652.8 & 475.7 & 146.0 & 557.0 & 407.6 & 179.3 & 701.0 & 538.8 & 271.8 & 649.6 & 530.8 & 263.8 & 630.0 & 412.0 & 224.0 \\
May & 653.3 & 486.8 & 266.8 & 650.0 & 445.7 & 186.4 & 756.5 & 602.4 & 248.9 & 729.1 & 570.5 & 339.0 & 616.0 & 346.0 & 182.0 \\
June & 666.8 & 468.3 & 129.5 & 627.7 & 415.0 & 169.4 & 793.7 & 579.7 & 251.7 & 760.8 & 570.8 & 310.1 & 480.0 & 292.0 & 184.0 \\
July & 568.5 & 424.3 & 231.0 & 559.0 & 330.5 & 116.6 & 800.1 & 525.3 & 221.2 & 757.6 & 537.8 & 279.2 & 545.0 & 291.4 & 119.7 \\
August & 566.0 & 384.2 & 171.8 & 492.7 & 292.8 & 124.0 & 716.0 & 477.5 & 183.6 & 704.1 & 503.2 & 278.9 & 431.5 & 266.3 & 134.9 \\
September & 606.7 & 406.6 & 141.7 & 479.7 & 284.3 & 70.0 & 680.3 & 499.7 & 157.9 & 629.8 & 494.0 & 277.5 & 487.2 & 216.0 & 76.0 \\
October & 515.8 & 420.4 & 234.3 & 413.4 & 307.6 & 149.0 & 602.3 & 476.8 & 239.0 & 559.4 & 464.5 & 290.9 & 444.7 & 245.1 & 54.7 \\
November & 480.7 & 348.8 & 190.7 & 356.2 & 254.2 & 123.2 & 482.8 & 388.0 & 229.8 & 443.4 & 354.4 & 234.2 & 446.2 & 296.1 & 129.0 \\
December & 348.3 & 287.1 & 141.8 & 294.5 & 206.9 & 96.0 & 422.8 & 339.8 & 184.6 & 452.0 & 366.5 & 199.1 & 397.0 & 226.2 & 103.7 \\
\hline Ann. mean & $\mathbf{5 5 0 . 4}$ & $\mathbf{4 0 4 . 3}$ & $\mathbf{1 6 6 . 0}$ & $\mathbf{4 6 5 . 5}$ & $\mathbf{3 1 0 . 0}$ & $\mathbf{1 2 7 . 0}$ & $\mathbf{6 2 7 . 8}$ & $\mathbf{4 7 1 . 4}$ & $\mathbf{2 0 7 . 8}$ & $\mathbf{6 0 7 . 7}$ & $\mathbf{4 6 4 . 2}$ & $\mathbf{2 4 6 . 4}$ & $\mathbf{5 0 8 . 5}$ & $\mathbf{3 0 2 . 6}$ & $\mathbf{1 3 7 . 8}$ \\
\hline
\end{tabular}

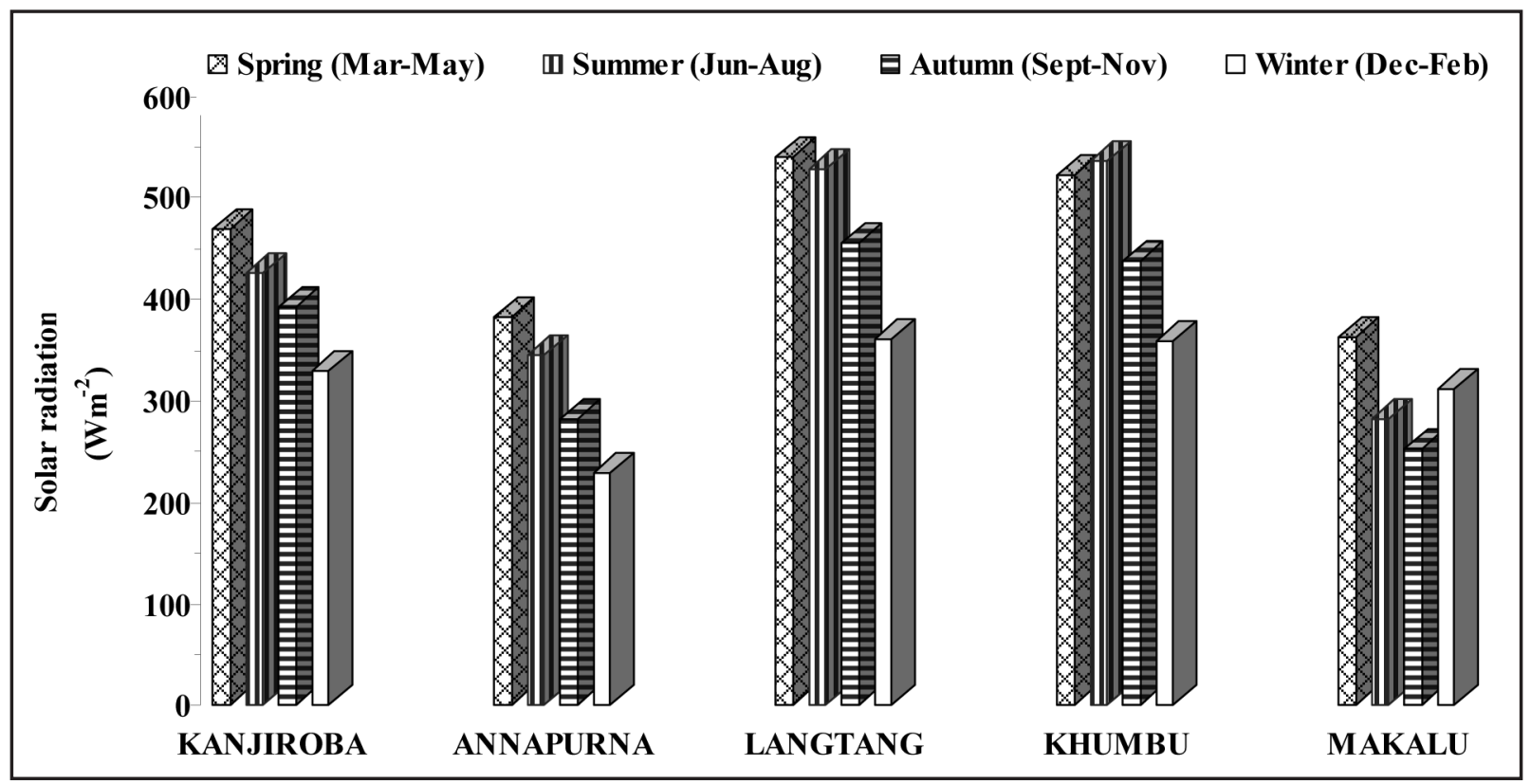

Figure 7: Mean seasonal variation of solar radiation in Kanjiroba, Annapurna, Langtang, Khumbu and Makalu. 
of solar radiation in Langtang and Khumbu are very similar. Both Langtang and Khumbu receive almost equal amount of seasonal solar radiation in spring and summer, while winter receives the least amount. In Annapurna and Makalu amplitudes of the seasonal mean solar radiation are much smaller than those of Langtang and Khumbu. Seasonal amplitude of Kanjiroba is moderate, but still lower than that of Langtang and Khumbu. There is a gradual decrease of solar radiation from spring to winter in all the stations except Makalu. In Makalu solar radiation of winter is higher than of autumn (it is even slightly higher than in summer), which is unusual. As the only data of 1993 and part of 1994 were available for Makalu, it is difficult to pinpoint the factor behind this discrepancy.

Figure 8 shows absolute extreme values of solar radiation observed in each station during fine weather conditions in 1993 as an example. It indicates that intensity of solar radiation is quite high in Nepal Himalayas during fine weather conditions. In particular, solar radiation in April-August is close to solar constant (1367 $\mathrm{Wm}^{-2}$ ).

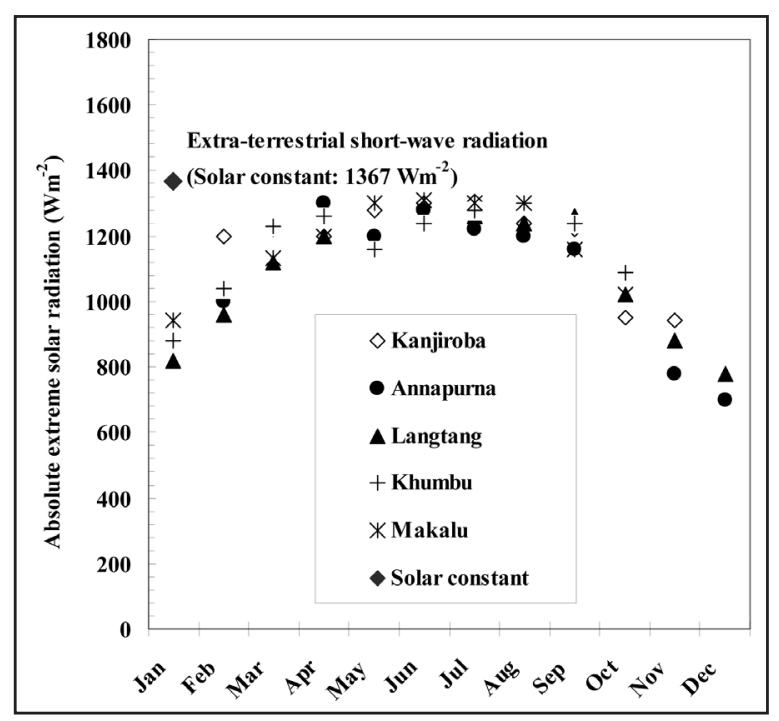

Figure 8: Absolute extreme values of solar radiation observed in each meteorological station during fine weather conditions (1993).
Figure 9 shows a comparison of monthly mean solar radiation recorded at various meteorological stations (except Makalu station) including Kathmandu Airport located at different altitudes and environments. Makalu meteorological station (solar radiation data available only for 1993 and part of 1994) is excluded in this comparison considering the limitation of the data. Monthly mean solar radiation is considerably higher during pre-monsoon months (April-June) than rest period of the year. The inset shows altitudinal variation of annual mean solar radiation. The linier regression resulted in $y=0.09 x+98.96$ (correlation coefficient is 0.75 ), where $\mathrm{y}$ is the annual mean solar radiation in $\mathrm{Wm}^{-2}$ and $\mathrm{x}$ is the altitude in meter. It is found that the increasing rate of the annual mean solar radiation with altitude is $90 \mathrm{Wm}^{-2} \mathrm{~km}^{-1}$ in the mountainous region of Nepal.

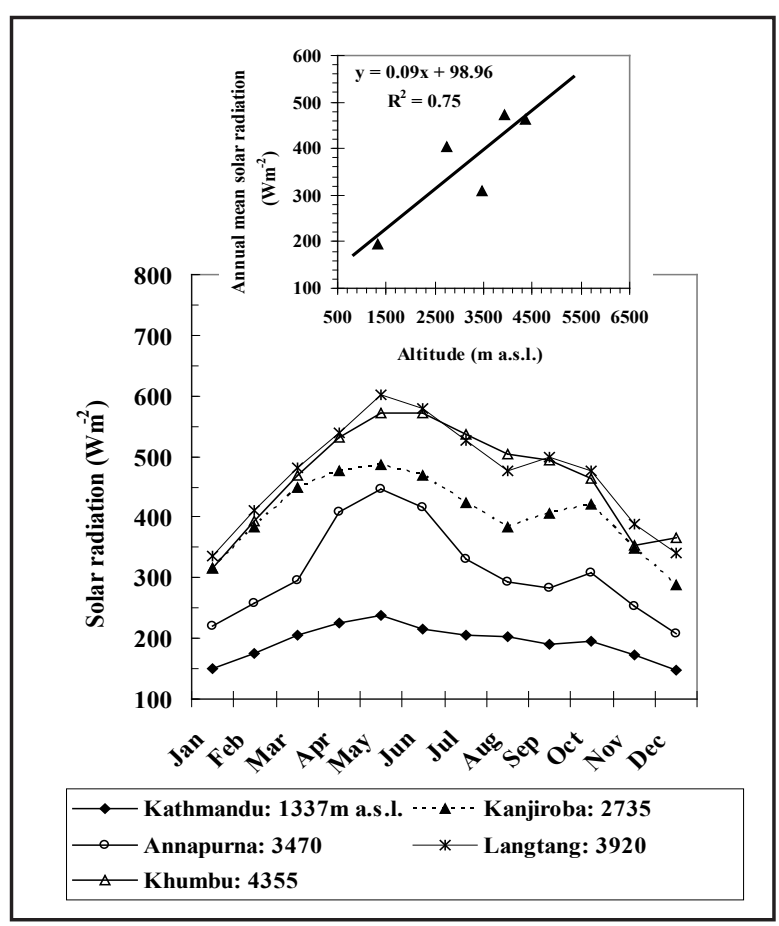

Figure 9: A comparison of monthly mean solar radiation recorded at various meteorological stations including the Kathmandu Airport located at different altitudes and environments. The inset shows altitudinal variation of annual mean solar radiation. 


\section{DISCUSSION}

The energy supply from the sun (solar radiation) is truly enormous (about $27 \times 10^{23}$ $\mathrm{kWs}^{-1}$ ) (Adhikari, 2007). As the solar radiation penetrates the atmosphere, some of the radiation is scattered, reflected or absorbed by the atmospheric gases, clouds and dust. Only a fraction of sun's radiation (energy) reaches on the earth's surface (on average 1.4 $\mathrm{kWm}^{-2}$ ). The main source of practically all of the energy for all physical and biological processes occurring on Earth is solar radiation, and it varies with latitude, altitude and period of year. Observations show that amount of solar radiation varied from month to month and from location to location (Oke, 1999; Nayava, 2012). The present research results obtained from the systematic data analysis revealed that mean solar radiation is generally higher in spring than in summer. In summer, the cloud formation in mountainous area is much denser compared to the cloud formation in the low-land area. Cloud density influences the amount of solar radiation that penetrates the clouds and reaches the earth's surface (Oke, 1999). This is the reason why lower amount of solar radiation was found during the summer rainy season than during the spring season (Figure 7, including Figure 2-6).

In the present study, absolute extreme values of solar radiation in the mountainous regions during fine weather conditions are found to be close to the solar constant $\left(1367 \mathrm{Wm}^{-2}\right)$ due to negligible depletion of radiation within the atmosphere (Figure 8). Solar radiation striking a surface perpendicular to the sun's rays at the top of the earth's atmosphere is called solar constant. This represents a practical upper limit for short-wave radiation in Earth-atmosphere system because the depletion of the atmosphere is not included. At high altitude, in a clear sky condition, smaller optical depth coupled with non interference of clouds allows higher amount of solar radiation to pass through the atmosphere and reaches the earth's surface.

The increase of solar radiation with altitude found $\left(90 \mathrm{Wm}^{-2} \mathrm{~km}^{-1}\right)$ in the present study (Figure 9, inset) substantiate with the results and interpretation given by Oke (1999). However, other factors, such as latitude, topography, weather and climate also affect significantly on amount of solar radiation (Paudel et al., 2011; Nayava, 2012).

\section{CONCLUSIONS}

In this study, I analyzed available data of solar radiation from different locations of Nepal Himalayas. Because of the high mountains and rugged terrain of the Himalayan region long term and continuous solar radiation data are limited. However, the results based on the available data set show significant similarities and differences on solar radiation input with respect to seasons and locations in Nepal Himalayas. The main findings of this study are summarized below.

1. Mean seasonal amount of solar radiation is generally higher in spring than in summer. The significant amount of monsoonal clouds in the summer hinders incoming solar radiation during summer while less or no clouds during spring allows more solar radiation to reach the earth's surface.

2. Absolute extreme values of solar radiation in the mountainous regions during fine weather conditions are close to the solar constant $\left(1367 \mathrm{Wm}^{-2}\right)$ due to negligible depletion of radiation within the atmosphere.

3. Amount of solar radiation increased with altitude due to smaller optical depth that solar radiation penetrates the atmosphere. The increasing rate of the annual mean solar radiation with altitude is found to be $90 \mathrm{Wm}^{-2}$ $\mathrm{km}^{-1}$ in the mountainous region of Nepal. 


\section{ACKNOWLEDGEMENT}

I thank Mr. Suresh Pradhan and Mr. Rajendra Dangol from Department of Hydrology and Meteorology, Ministry of Environment, Science and Technology, Government of Nepal for providing solar radiation data utilized in this research. I am grateful to the anonymous reviewer for important comments and suggestions on the final draft of this paper.

\section{REFERENCES}

Adhikari, S. 2007. Synthesis and Characterization of Carbon Thin Films and their application to Photovoltaic solar Cells. Ph.D. Dissertation. Chubu University, Japan.

Department of Hydrology and Meteorology (DHM) 1992. Snow and Glacier Hydrology Data Year Book (1987 to 1992). SGHU, Dept. Hydrology and Meteorology, Govt. of Nepal.

DHM 1993. Snow and Glacier Hydrology Data Year Book (1993). SGHU, Dept. Hydrology and Meteorology, Govt. of Nepal.

DHM 1994. Snow and Glacier Hydrology Data Year Book (1994). SGHU, Dept. Hydrology and Meteorology, Govt. of Nepal.

DHM 1995. Snow and Glacier Hydrology Data Year Book (1995). SGHU, Dept. Hydrology and Meteorology, Govt. of Nepal.

DHM 1996. Snow and Glacier Hydrology Data Year Book (1996). SGHU, Dept. Hydrology and Meteorology, Govt. of Nepal.

DHM 1997. Snow and Glacier Hydrology Data Year Book (1997). SGHU, Dept. Hydrology and Meteorology, Govt. of Nepal.
DHM 1998. Snow and Glacier Hydrology Data Year Book (1998). SGHU, Dept. Hydrology and Meteorology, Govt. of Nepal.

DHM 1999. Snow and Glacier Hydrology Data Year Book (1999). SGHU, Dept. Hydrology and Meteorology, Govt. of Nepal.

Ibrahim, S.M.A. 1985. Predicted and measured global solar radiation in Egypt. Solar Energy 35: 185-188.

Nayava, J.L., 2012. Climates of Nepal and their implications, WWF Nepal. Pages 164.

Oke, T.R. 1999. Boundary Layer Climates (second edition). University Press, Cambridge. Pages 435 .

Paudel, K.N., Bhattarai, B.K., Sapkota, B., and Kjeldstad, B., 2011. Solar Radiation Potential at Four Sites of Nepal. Journal of the Institute of Engineering, Vol. 8, No. 3, pp. 189-197.

Schweizer-Ries P., and K. Preiser. 1997. SocioTechnical analysis of solar home systems in the Nepalese Himalaya. 14 ${ }^{\text {th }}$ European Photovoltaic Solar Energy Conference, Barcelona, Spain. Pages 2552-2555.

Schweizer P., J.N. Shrestha, and D. Sharma. 1995. What can Solar Electricity provide for the Himalayan People? The case of Nepal. $13^{\text {th }}$ European Photovoltaic Solar Energy Conference and Exhibition, Nice: E.C., France. Pages 1791-1795.

Umeno, M. 2003. Research and development of amorphous carbon thin film solar cell supported by NEDO (in Japanese). Antenna No. 54: 1-2. 